\title{
English-Teaching Problems in Thailand and Thai Teachers' Professional Development Needs
}

\author{
Sripathum Noom-ura ${ }^{1}$ \\ ${ }^{1}$ Language Institute, Thammasat University, Thailand \\ Correspondence: Sripathum Noom-ura, Language Institute, Thammasat University (Rangsit Campus), \\ PathumThani 12120, Thailand. Tel: 66-2-696-6008. E-mail: sripathum.n@gmail.com
}

Received: July 26, 2013 Accepted: August 27, 2013 Online Published: October 10, 2013

doi:10.5539/elt.v6n11p139 URL: http://dx.doi.org/10.5539/elt.v6n11p139

The research is financed by the Language Institute, Thammasat University, Thailand.

\begin{abstract}
This study surveys problems with English language teaching and learning and the professional development (PD) needs of high-school teachers in three provinces of three Secondary Educational Service Areas in Thailand. Both closed-and open-ended questionnaires were employed. The data was analyzed by frequency distribution and percentage; the problems and PD needs are herein presented from highest to lowest ranking. The study's results may possibly be generalized so that local organizations and institutions of higher education can provide appropriate assistance and improve the English teaching situation in Thailand in general.
\end{abstract}

Keywords: English teaching problems, professional development, PD needs, education, Thailand

\section{Introduction}

\subsection{English Education Failure in Thailand}

Thai students spend twelve years studying English in primary and secondary schools, but the results are questionable. When compared to people in neighboring countries, Thais' English proficiency is relatively low. The 2010 Test of English as a Foreign Language (TOEFL) showed that Thailand ranked $116^{\text {th }}$ out of 163 countries. The Netherlands topped the list with an average score of 100 out of 120 , followed by Denmark and Singapore with the average scores of 99 and 98 respectively. The international average score was 80 but the Thai average score was 75, which was a little higher than the average scores of Cambodia, Laos, Vietnam, and Myanmar, but was trailing far behind other ASEAN countries such as Indonesia, Malaysia, the Philippines, and Singapore. On the 2011 report, the Thai average score was still the same, 75 (Test and Score Data Summary for TOEFL, 2011-2012).

In addition, in the most recent Education First English Proficiency Index (EF EPI, 2012) released in October, 2012, Sweden and Denmark ranked first and second, Singapore twelfth, and Thailand $53^{\text {rd }}-$ the world's second-lowest rank (above only Libya) - with an average score of 43.36 and labeled 'very low proficiency'.

When the English-proficiency test results within Thailand were examined, the O-NET (Ordinary National Educational Test) revealed that the English average scores of Thai primary school students in 2010 and 2011 were, out of 100, 31.75, and 20.99 respectively. The average scores between 2009 and 2011 of 900,000 lower secondary-school students were 32.42, 26.05, and 16.19 respectively. Among 350,000 upper secondary-school students, the English-language average scores (2009-2011) were 30.68, 23.98, and 19.22 (O-NET reports, 2012). These poor results were controversial. Some doubted the consistency and validity of the tests, while others questioned the teaching and learning practices in English-language classes in Thai schools.

\subsection{Causes of Failure}

Upon examining the English-language classes, many researchers pointed to a few main factors contributing to the failure of English-language teaching-and-learning: unqualified and poorly-trained teachers, poorly-motivated students, learners of mixed abilities in overly large classes, and rare opportunities for student exposure to English outside of class time (Dhanasobhon, 2006; ONEC, 2003).

Wiriyachitra (2002, citing Biyaem, 1997) compiled the causes of difficulties in English language teaching and 
learning in Thailand especially in the primary and secondary schools. Some of the problems she posted were: teachers' heavy teaching loads, inadequately equipped classrooms and education technology, the university entrance examination system, teachers' insufficient English language skills and cultural knowledge. The problems involving students who wished to speak English fluently included challenging interference from Thai language, lack of opportunity to use English in their daily lives, unchallenging English lessons, being passive learners, being too shy to speak English with classmates, being poorly-motivated and lack of responsibility for their own learning. These problems have been attributable to the unsatisfactory results of English language teaching as mentioned earlier.

However, according to Geringer (2003), the most important factor in student learning progress is the teachers, and teacher quality outweighs other factors such as motivation, funding, and class sizes. Qualified teachers can create the best environment for learning. As for Thailand (Education in Thailand, Wikipedia), a survey, in collaboration with the University of Cambridge, measuring the qualifications of four hundred Thai teachers of English, found that a full $60 \%$ of them had knowledge of English and teaching methodologies below that of the syllabus level at which they were teaching. Of the remaining top $40 \%$, only $3 \%$ had a reasonable level of fluency, and only $20 \%$ were teaching class-levels for which they were both qualified and competent. Noopong (2002) also reported that $65 \%$ of primary school teachers who were teaching English had not taken English as their major of their studies, and only around 70\% of secondary school English teachers graduated with a bachelor's degree in English. Dhanasobhon (2006) explained that at the secondary level, there is a shortage of teachers of English because English majored graduates love to work in other higher salary jobs such as flight attendants, or in hotel and tourism businesses, or with private companies.

In addition to the lack of qualified teachers, it is widely understood that what is expected from teachers these days is multi-faceted. They are required to teach effectively in challenging environments; to make effective use of information and communications technology (ICT) in their teaching; to cater to a variety of learning styles (as elaborated in Gardner's Theory of Multiple Intelligences, 1993); to conduct research aimed at improving the quality of their teaching; and to deal effectively with multitudinous administrative tasks -- all of which to meet up with the requirements for 'Quality Assurance.' Moreover, most Thai teachers of English, especially at the secondary level, have to teach at least eighteen hours a week on average and often take on additional classes outside regular school hours in order to supplement their relatively meager salaries. Because of overloaded burden, their teaching styles start to fossilize into ones of rote-learning, teaching grammar and translation with Thai as the medium of instruction, teacher-centered classroom activities, spoon-feeding, and so on.

\subsection{Attempts to Improve the Situation}

Institutions of higher education realize this fact and try to give assistance by organizing training sessions, seminars, and conferences for teachers at all levels of ability and experience: novice teachers, teachers with some experience, and teachers able to play more advanced roles as leaders or trainers. Also, the Thailand Education Reform implemented between 1996 and 2007 emphasized teacher development, and teachers would be offered continuous training with some form of training such as attending seminars, workshops, or conferences every two years (Wiriyachitra, 2002).

The Language Institute of Thammasat University (LITU), no less than many other institutions of higher education, has been organizing professional development training courses for thousands of English teachers from various high schools. The trainees, through the end-of-course evaluation form, have been reporting high levels of satisfaction with the training. However, the design and the implementation of professional development training courses, which focused mainly on lesson-planning and teaching methodology, emphasizing how to teach each skill and how to teach integrated skills, was in a sort of top-down and non-collaborative manner. In other words, teacher participants had no opportunity to influence or change the content or delivery of the professional development activities and materials being provided.

Colbert, Brown, Choi \& Thomas (2008) stated that improving teacher quality is both common and necessary, and it depends on professional development, which should create meaningful learning experiences for teachers. However, while teachers are required to participate in professional development activities, it is often the case that they are not involved in selecting and planning those activities, and that professional development may not be closely tied to classroom practice. Teachers attended the courses available to them, which may or may not have directly served their needs. They may very well have returned to their schools and faced the same problems they had before, or they may have been fortunate enough to be able to modify their classroom practices using what they gained from the training. Therefore, a more desirable PD training course should provide some opportunities for participants to be involved in choosing the problems for which they've been searching solutions (Zeichner, 
2003; Sparks, 2004; Bonner, 2006).

Recently LITU was requested by a high school to run a training course for their teachers on Advanced Reading-Writing and Essay Writing. The course was a kind of teacher-driven professional development activity. The teachers analyzed their own needs and specified what type of training they wanted. They were interested in gaining all sorts of skills required for teaching highly-motivated and above-average students: classroom management, instructional skills, and in improving their own language proficiency. This school is not quite typical in that it aims to become a world-class science school. In order to help with financial support and to encourage cooperation among peers, the school collaborated with a few local high schools, encouraging participants from them to join the training so that costs could be shared.

The outcome of this course was highly satisfactory. The average score from 31 participants representing the course satisfaction, which included the course content, activities, and other relevant concerns, was 4.91 out of 5 of the ranking scale. Thus was the researcher inspired to speculate as to whether the aforementioned training courses satisfactorily served the needs of the participants. Could the training activities be initiated and conducted by the participating teachers themselves instead? Mightn't it be more fruitful if they had opportunities to choose their own areas of interest, establish networks and interact with peers who share common interests?

In addition, another issue came to mind. The interested participants, except for those from the initiating school, paid their own fees or were partially supported by their schools, and they spent five weekend-days to participate in the course. Such willingness supports the idea that school teachers inadequately get opportunities and support for professional development despite their interest in self-improvement in their chosen careers. Opportunities for them to attend seminars such as the annual Thailand TESOL conferences are rare. Each year, LITU finances more than fifteen teachers to participate in said conferences, both as presenters and attendees, while teachers in some schools sign up to show their desire to attend the conferences, but only a few from each school get both permission and financial assistance to do so (personal communication with three teachers from three secondary schools at a conference, January 2012).

In fact, the Ministry of Education has been giving assistance to teachers by already setting up 88 English Resource and Instruction Centres (ERIC) in many educational regional areas. One of the activities organized by an ERIC is to run professional development sessions for English teachers. Some interesting questions are raised: Have those sessions adequately and directly served the teachers' needs? Have the teachers had opportunities to say what their problems are and what kind of professional development they need? What level of difficulties teachers are having in their teaching context?

Apart from the teacher quality, the student motivation, the curricula and textbooks, the assessment methods, and other supporting factors such as teaching aids, class sizes, and time allocation are often said to exacerbate the English language teaching problems in Thailand. Thus, with the present unsatisfactory results of English language teaching and learning and obvious desires for professional development of English teachers, the researcher aimed to get a clearer picture of the problems secondary school teachers are facing and to find out if those teachers need any kind of professional development.

\section{Research Methodology}

\subsection{Research Objectives}

1) To survey English-teaching problems related to the teachers, students, assessment, curricula and textbooks, and other factors contributing to successful teaching in secondary schools.

2) To investigate the needs for professional development of English language teachers in those schools.

\subsection{Subjects of the Study}

This quantitative survey study was conducted on a rather small scale. The sample was thirty-four teachers of English language from nine schools from three Secondary Educational Service Areas (SESAs) in central Thailand. There were altogether 77 secondary schools in these SESAs, and three schools were randomly selected from each SESA. The Head of the Foreign Language Department of each school helped distribute the questionnaires to all forty-seven English teachers, collect the replied questionaires and post them back to the researcher the following week. The returning rate of the questionnaire was $72.34 \%$.

\subsection{Research Instrument}

The questionnaire (in Thai) consisted of three parts:

Part I requested personal information about the teacher and school, the teacher's qualifications, teaching experience, workload, and PD experience during the past two years. 
Part II was concerned with English-teaching problems divided into five subcategories:

1) Problems involving teachers (20 items). The questions included teachers' qualifications related to ELT, their competence in using English in class, problems with using ICT, teaching main skills and/or integrated skills of English, using techniques for arousing learners' interest, and their own opportunities to be exposed to English language.

2) Problems involving students (20 items). Examples of questionnaire items involved student attitudes towards English, motivation, insufficient knowledge and basic skills of English, and opportunities to practice or experience the use of the language.

3) Problems involving curricula and textbooks (10 items). It included curricular objectives, coverage of the content, textbooks mandated, and lack of expert curriculum advisors.

4) Problems involving assessment (9 items). This section included lack of knowledge or abilities in creating tests of different language skills, appropriateness of each test types, etc.

5) Problems involving other factors contributing to successful teaching and learning (10 items). Such factors included funds and support in production or adaptation of teaching materials and teaching aids, sufficiency of English native speakers in schools, class size and time allocation for English subjects, and availability of the language laboratories or computers in the schools.

In addition, there was an open-ended question asking: What are other English-teaching problems you are facing?

Part III was concerned with teacher-perceived needs for professional development. It comprised two subsections: types of PD (13 items), and content areas of PD (25 items). Some examples of the former included short term and long term training courses, in-house training, study trips, and workshops. The latter included the training courses on English-language proficiency, teaching methodology of English and communicative skills, and conducting classroom research.

There were also two open-ended questions: Are there any other types or content areas of PD you need? If/When not getting financial support from school, are you willing to pay for your own professional development?

\subsection{Data Analysis}

The demographic information was analyzed and descriptive statistics of frequencies, percentage, mean and standard deviation were used to measure the levels of agreement to the statements concerning teaching problems and needs for professional development. An average score of a 5 rating scale was interpreted to show levels of agreement to each questionnaire item as the following: 4.51-5.00 representing very high level of agreement; 3.51-4.50, high; 2.51-3.50, moderate; 1.51-2.50, low; and 1.00-1.50, very low.

\section{Research Findings}

\subsection{Information about the Respondents}

The findings show several features typical of Thai teachers of English. For example, the stereotyped gender of English teachers in Thailand is female. It comprises $82.3 \%$ of the subjects in this study. The majority $(91.2 \%)$ of the secondary school teachers is bachelor's degree holders and $8.8 \%$ have a master's degree in ELT. A minority of the subjects are novice teachers while over half of them have been in service for more than fifteen years, and their teaching workload is about 16 to 20 hours per week, excluding administrative tasks. Over $55 \%$ of the respondents had no more than 3 days of PD experience, while only about $14 \%$ of them had more than 10 days of $\mathrm{PD}$ experience during the past two years.

\subsection{Responses to Research Objective One}

To survey English-teaching problems related to teachers, students, curricula and textbooks, assessment, and other teaching support in the nine schools from three SESAs.

The findings from this section can be presented in the following figure. 


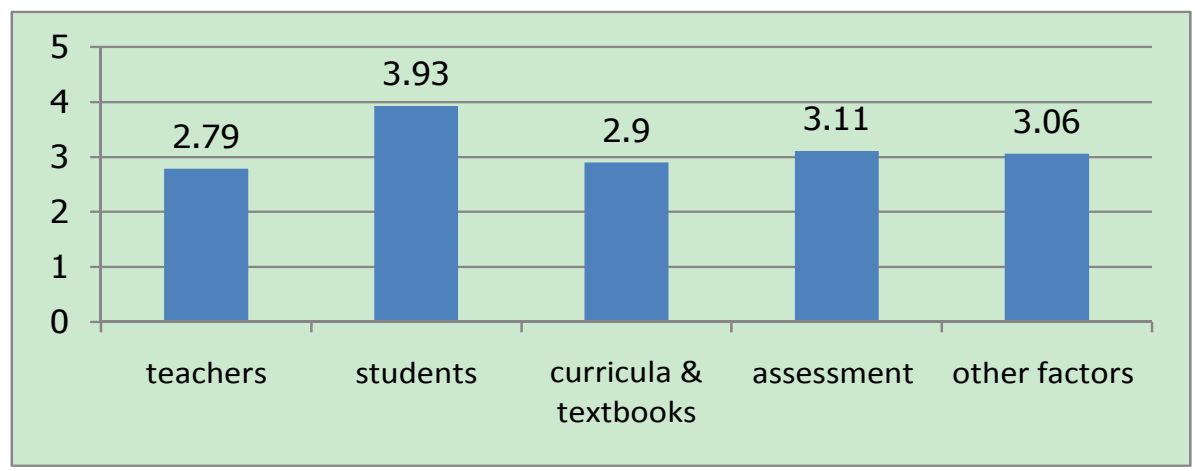

Figure 1. English teaching problems in Thailand

As can be seen from Figure 1, students were seen attributing to English teaching problems at a high level while problems involving teachers, curricula and textbooks, assessment and other factors contributing to successful teaching problems were rated at a moderate level. The highest and lowest ranks of each category are as follows:

\subsubsection{Problems Involving Teachers}

The respondent-teachers moderately agreed with the problems involving themselves. The top five highest ranks of their problems were concerned with 1) teaching writing, 2) incorporating experiential learning into English classes, 3) their own minimal use and/or exposure to English, 4) teaching listening and speaking, and 5) using games and songs effectively in English classes (mean scores: 3.35, 3.29, 3.21, 3.06, and 3.06 respectively).

In contrast, they showed a low level of agreement with four statements concerning 1) their dislike of teaching English, 2) their lack of English teaching qualifications, 3) problems with teaching vocabulary, and 4) problems with teaching grammar and structure (mean scores: 1.62, 2.18, 2.38, and 2.44 respectively).

\subsubsection{Problems Involving Students}

The respondents agreed at a high level that students were a problematic factor in the success of their teaching. Eight items got the mean scores of over 4. The highest problems included 1) students not having enough practice in English on their own, 2) students lacking opportunities for English exposure outside class, 3) students' insufficient knowledge and skills of English, 4) students thinking in Thai before translating to English, 5) students having problems with writing, 6) students lacking patience in practicing English, 7) students having problems with listening and pronunciation, and 8) students lacking confidence in speaking English (mean scores: 4.38-4.06). Only two items were seen as problematic at a moderate level: the students' views on the usefulness of English and their wish to be taught by native speakers of English (mean scores: 3.09 and 3.50).

\subsubsection{Problems Involving Curricula and Textbooks}

Responses relating to curricula and textbooks were at the moderate level. The top five problematic areas involved 1) the impracticality of the guidelines for managing activities in the curricula, 2) the curricula having too much to cover, 3) teachers not understanding the details of the curricula, 4) the inappropriateness of the curricula for local conditions, and 5) teachers lacking expert curriculum advisors (mean scores: 3.38-2.97). The problems with the curricula not being up-to-date and teachers lacking opportunities to choose their own textbooks were perceived at a low level (mean scores: 2.41 and 2.47).

\subsubsection{Problems Involving Assessment}

The teachers felt they had a moderate level of problems about assessment. The items that indicated a rather high degree of problems involved 1) assessment of listening-speaking skills, 2) writing, and 3) listening (mean scores: 3.38-3.29). The least problematic aspect was the ability to construct tests of grammar and structure, and vocabulary (mean scores: 2.71 and 2.97).

\subsubsection{Problems Involving Other Factors}

When asked about other factors contributing to teaching success, the teachers had a moderate opinion about this. The highest ranked problems involved 1) inadequate supplies of computers and language laboratories to aid teaching, 2) lack of teachers who were English native speakers, and 3) limited time-allocation for English classes (mean scores: $3.35-3.15$ ). They saw large classes as less problematic as inadequacy of teaching aids (mean $=$ $2.85)$, while the least problem involved funds available for teacher professional development $($ mean $=2.79)$. 
Additionally, a few respondents emphasized at the open-ended section on their overloaded teaching and administrative tasks; everyone had been responsible for more than three administrative tasks. About ten teachers said students lacked patient and additional practice of English outside class; students always came back to class with blank eyes. A few respondents pointed out their obligation to teach students in a tutorial manner for school examinations and the university entrance examination, rather than teaching for communication.

\subsection{Responses to Research Objective Two}

To investigate the professional development needs of English language teachers in those schools. The summary of the findings is as follows:

\subsubsection{Types of PD Needs}

The respondents showed a moderate level of PD needs. The most valued PD types involved 1) three to five days of training, seminars or conferences, 2) study trips in Thailand and overseas and 3) furthering their study either in Thailand or overseas (mean scores: 3.59-3.38). The respondents showed the least attention to the two to three month training courses (mean $=2.79$ ).

\subsubsection{Content Areas of Professional Development}

Although the respondents showed a moderate level of PD needs, surprisingly, they showed a high level of agreement on every single content area listed in the questionnaire. There were top seven areas yielding the mean scores of over 4, which included 1) teaching strategies that enable students to communicate in English, 2) their own English proficiency development, especially in listening-speaking and writing skills, 3) teaching listening-speaking to students, 4) teaching language and culture, and 5) teaching writing (mean scores: 4.15-4.00). The area that seemed the least problematic or needed was knowledge about using a student-centered teaching approach, even though the mean score was quite high (mean $=3.56)$.

Also, from the responses to the open-ended questions, $37 \%$ of them were willing to cover for their own expenses if/when they could not get financial support from their school for the PD programs they wanted to attend. Two of them said most available PD programs crashed with their heavy teaching schedules.

\section{Discussion}

When compared the study results to the findings reported by Noopong (2002), the perceptions of both groups of teacher-respondents were similar and different in many ways. For example, Nopong's study similarly revealed that most of the problems concerning teachers, curricula and textbooks, and student assessment were at a moderate level, while most of those concerning students were at a high level. However, while the current study found that other factors contributing to successful teaching such as lack of English native speakers, inadequate budget for teaching materials, insufficient financial support for teachers' PD and students' extra-curricular activities, and inaccessibility for language resources were seen as moderately serious problems, Noopong reported them as the most serious problems for language teaching. The findings of the current study may attribute to two main questions to be discussed:

Question 1: Although many English test results of Thai people or Thai students were unsatisfactory as mentioned earlier, why were problems involving teachers, curricula and textbooks, assessment, and factors contributing to successful teaching seen at a moderate level in the current study?

It is likely that two main reasons are involved in answering this question. First and foremost, the Thailand Education Reform Project, 2002, may have helped subside the seriousness of the problems as cited in Tantranon (2009):

In the year 2006, several projects have been undertaken to enhance the quality of education and the quality of teachers. Resources and investment for education and development of teachers, faculty staff and educational personnel have been allocated to raise the standards and professionalism in terms of ethics, as well as academic skills. There were large number of teachers and education personnel who attended conferences and training courses to support their continuing professional development (CPD) in Local Education Service Areas across the country. The Ministry of Education (MOE) also supports CPD activities in schools and the use of computers and access of internet for networking between teachers to share new teaching and learning techniques. These collaborative networks both online and face-to-face activities facilitated interaction and sharing of experiences and common interests and lead to further improvement in the classroom. (p. 31)

This means that each English teacher should have experienced some kinds of PD, and most secondary schools of today have probably been better-equipped with facilities necessary for language learning and teaching. This may support the findings that the respondents disagreed with the statements that they disliked teaching English or 
they had problems with their qualifications. Nor did they agree that the problems about facilities supporting teaching were serious.

The second reason that may help explain the situation of English-language teaching is that Thai teachers of English seem to cope surprisingly well with presumed common problems such as overly large classes, limited and impractical curricula and textbooks, difficulties with language assessment, and limited availability of computers and other instructional aids. They have made do with what they have and rated the problems as moderately serious. In addition, they seem to have been doing well in some particular areas. For example, they disagreed that they had serious problems concerning teaching and constructing the tests of vocabulary, grammar and structure.

However, the skills focus that teachers of ten years ago perceived important were reading and writing skills, while teachers of this current study wished to improve teaching strategies for communication skills. As the findings revealed, the teachers' top five problematic areas, although at a moderate level, involved teaching writing, incorporating experiential learning into English classes, their own minimal use or exposure to English, teaching listening and speaking, and using games and songs effectively in English classes. Also, the teachers' PD needs shifted from those of Noopong's teachers, who requested strategies for teaching reading, writing, and knowledge of psychology in teaching respectively, to the needs of equipping teachers with strategies for teaching listening-speaking or conversation and writing.

Thai teachers of English in this study focused more on developing their own and their students' productive skills such as speaking and writing probably because of their weaknesses in these areas. It is widely accepted that Thais, even university graduates, have much difficulty successfully communicating in English. According to Suwanarak and Phothongsunun (2009), half of undergraduate students participating in their study pointed out that they were unable to use English to communicate in real situations as they were weak in listening and speaking skills. They attributed the failures to themselves - having made little effort in practicing English. These students' responses may, to some extent, give the answer to the following second discussion question.

Question 2: Why were the problems involving students seen at a high level by both studies?

While the problems involving teachers were assessed at a moderate level, the problems involving students were rated high. Above all, the respondents thought that students did not practice English enough in their own time, students thought in Thai before translating it into English when struggling to communicate, and students had problems with writing and pronunciation. Moreover, students lacked patience in practicing English and had little exposure to English outside class, which may in turn contribute to their lack of confidence in speaking English. Nevertheless, the teachers perceived that students could see the importance of English, and some of them wanted to study English with native speakers. Still, from the open-ended question section, about ten teachers mentioned that students did not pay enough attention to English studying, and nor did they have enough practice of English in their own time. A teacher wrote: 'Students usually came back to my English class the following week with 'blank eyes' as if they had never at all heard anything I was trying to review and link with the new lesson.'

The findings from teachers' perceptions in both studies similarly indicated the students' lack of patience practicing English and students' minimal exposure to English outside class. These two causes of failure seem impossible to solve in Thailand context. Many researchers (e.g. Dodds, 1994; Williams and Burden, 1999; Whitley and Frieze, 1985 - cited in Suwanarak \& Phothongsunun, 2009) emphasized two factors contributing to success or failure of learning and teaching: the students themselves, and the teachers. The former - regarding their motivation and attitudes - is regarded as an internal factor affecting learning. It outweighs the latter, an external factor, which involves teaching contexts and the learning environment. In other words, no matter how well teaching strategies are employed, success seems out of reach without student perseverance. This seems to be real worrying because if English study results are still unsatisfactory internationally as mentioned earlier, English will be a great barrier for future Thais to be competitive in employment to economists, engineers and scientists from Malaysia, Singapore and the Philippines. The agreement of the 'Free Flow of Skilled Labor' or 'Mobility of professions in ASEAN community' set out in 2015 will be advantageous to other ASEAN nationals who are more fluent in the ASEAN lingua franca and the international language of science, business, tourism, etc.: English. The teacher-respondents have shown their real concern and awareness in improving the learners' and their own communication skills. Thus, in terms of professional development, a training course that gives priority to such skills should be valuable. Also, the findings revealed that the teachers seemed to have greater difficulties with the assessment of listening-speaking skills, writing, and listening; therefore, organizers of PD programs should be aware of such needs. 
Another highly-rated problem involving students is their insufficiency in the knowledge of English language. Although secondary school students have studied English for about 500 hours from their six years of elementary schools, their basic skills are very limited. Again, they seldom have exposure to or practice of English outside class. In the researcher's view, it is rather depressing to discuss Thai learners' exposure to English language. Most of them have three hours of English per week, resulting in forty-five hours per semester or ninety hours per year. According to Archibald et al.(2006, p. 3), "Learning a second language for 95 hours per year for six years will not lead to functional bilingualism and fluency in the second language. Expectations must be realistic." A book that should be introduced to our learners is entitled "Outliers" by Malcom Gladwell (2008), who 'highlights the research behind the notion that true expertise is achieved after an individual has invested 10,000 hours in learning or practicing a skill.' He investigated the success of Bill Gates, the Beatles, and other great achievers; they all acquired wealth and fame through the true key to success-'a matter of practicing a specific task for a total of around 10,000 hours.' If we take a close look at hours spent for EFL instruction in Thailand, ninety hours of English classes per year, an individual student, to attain 10,000 hours of practice and achieve expert fluency, needs at least 100 years! This has not yet taken individual or context differences into account. Although some may want to argue that not all Thai learners of English want to attain 'an expert level' or spend that much of intense training, it indicates that one of the critical flaws of Thailand education is the lack of emphasizing that learning must be done at all times and in all contexts: formal, non-formal and informal (Eaton, 2011). English language learning is obviously insufficient if it takes place only in the classroom. Teachers, thus, should be trained to offer strategies and guidance that promote or encourage students' self-directed learning and create their affection to learn. For those who love learning, the more they study or learn, it will naturally follow that both their comprehension and production skills will be improved.

\section{Conclusion}

From this study, Thai teachers of English view the problems involving themselves, curricula and textbooks, assessment, and other factors supporting teaching success at a moderate level. They see a high level of problems resulting from students'lack of exposure to English and insufficient background of the language. Students' lack of perseverance in practicing or seeking more opportunities to practice the language also contributes to their lack of confidence in using language for communication. Although the teachers' needs for professional development and for PD funds are at the moderate level, they are aware of continuing professional development and availability of PD programs. They show a high level of interest and value to all areas contributing to their career success: their own English proficiency, and instructional/pedagogical strategies for teaching and assessing productive skills such as listening-speaking and writing skills in particular.

\section{Recommendations for Further Study}

1) Although this study was on a small scale basis, the findings might provide a condensation of the content areas of professional development programs that need to be organized in the future. Teachers see the necessity of teaching productive skills such as listening-speaking and writing over the teaching of reading and grammar and structure. The training courses that help improve teachers' English proficiency are also highly valued.

2) For any PD program that is well established, it is worthwhile to conduct a follow-up study to find out whether the participants are henceforth able to solve their teaching problems or apply what they gain from the program in their teaching situation. Alternately, a teacher-driven PD program may be more valuable because it may result in the delivery methods and the content areas that directly serve the participants' needs.

3) The current study presents only the teachers' perspectives on English-teaching problems; it may be worthwhile to take the other side of the coin i.e. Thai learners' views on English teaching and learning problems into consideration, too.

4) There should be some research conducted on number of hours of exposure necessary for Thai learners to become moderately proficient users of English. This may help advocate self-directed learning or help policy makers see the necessity to provide more time-allocation for English classes, hire more English native speakers, or support using English in teaching other subjects to increase students' English exposure.

\section{References}

Archibald, J., Roy, S., Harmel, S., Jesney, K., Dewey, E., Moisik, S., et al. (2006). A review of the literature on second language learning (2nd ed.). University of Calgary. Language Research Centre.

Bonner, P. J. (2006). Transformation of teacher attitude and approach to math instruction through collaborative action research. Teacher Education Quarterly, 33(3), 27-35. 
Colbert, J. A., Brown, R. S., Choi, H., \& Thomas, S. (2008). An investigation of the impacts of teacher-driven professional development on pedagogy and student learning. Teacher Education Quarterly, 35(2), 135-154.

Dhanasobhon, S. (2006). English language teaching dilemma in Thailand. Retrieved January, 2013, from $\mathrm{http}: / / \mathrm{www}$. curriculumandinstruction.org/index.php?lay=show\&ac $=$ article \&Id=539134523\&Ntype=7

Eaton, S. E. (2011). How long does it take to learn a second language? Applying the "10,000 hour-rule" as a model of fluency. Onate Press. Calgary. Canada.

Education in Thailand. (n.d.). In Wikipedia, the free encyclopedia. Retrieved December, 2012, from http://en.wikipedia.org/wiki/Education_in_Thailand

EF English proficiency index. (2012). Retrieved November, 2012, from http://www.ef.co.th/epi/downloads/

Gardner, H. (1993). Multiple intelligences: The theory in practice (10th ed.). New York: Basic Books.

Geringer, J. (2003). Reflections on professional development: Toward high-quality teaching and learning. Phi Delta Kappan, 84(5), 373.

Gladwell, M. (2008). Outliers: The story of success. New York: Little, Brown and Company.

Noopong, D. (2002). English teaching problems and the needs for professional development of teachers of English in education extended schools under the Jurisdiction of the Office of Primary Education, Nakhon Ratchasima. Nakhon Ratchasima Rajabhat University. English Program.

ONEC. (2003). Education in Thailand 2002/2003. Bangkok: ONEC Publication.

O-NET reports. (2012). Retrieved November, 2012, from http://www.onesqa.or.th/onesqa/th/download/index.php?

Sparks, D. (2004). The looming danger of a two-tiered professional-development system. Phi Delta Kappan, 86(4), 304-308.

Suwanarak, K., \& Phothongsunan, S. (2009). Attributions of high achieving Thai university students perceiving themselves as failures in English usage. Retrieved July, 2012, from http://km.nida.ac.th/home/images/pdf/8-3.pdf

Tantranont, N. (2009). Continuing professional development for teachers in Thailand. Doctoral thesis, University of Warwick, Institute of Education. Retrieved December 10, 2012, from http://wrap.warwick.ac.uk/2242/

Test and score data summary for TOEFL internet-based and paper-based tests. (2011). Retrieved October, 2012, from http://www.ets.org/Media/Research/pdf/TOEFL-SUM-2010.pdf

Test and score data summary for TOEFL iBT ${ }^{\circledR}$ tests and TOEFL ${ }^{\circledR}$ PBT tests. (2012). Retrieved January, 2013, from http://www.ets.org/s/toefl/pdf/94227_unlweb.pdf

Wiriyachitra, A. (2002). English-language teaching and learning in Thailand in this decade. Thai TESOL Focus, 15(1), 4-9.

Zeichner, K. (2003). The adequacies and inadequacies of three current strategies to recruit, prepare, and retain the best teachers for all students. Teachers College Record, 105(3), 490-515.

\section{Copyrights}

Copyright for this article is retained by the author(s), with first publication rights granted to the journal.

This is an open-access article distributed under the terms and conditions of the Creative Commons Attribution license (http://creativecommons.org/licenses/by/3.0/). 